\title{
ADVANCES IN THE REVIEW OF GENERIC DRUG APPLICATIONS BY UNITED STATES FOOD AND DRUG ADMINISTRATION, A REGULATORY PERSPECTIVE IN THE ERA OF GDUFA (GENERIC DRUG USER FEE AMENDMENT 2012)
}

\author{
Available online at www.ijdra.com
}

\section{REVIEW ARTICLE}

\author{
Maddela Lakshmi Kanth*, Insukh Oh
}

Daewoong Pharmaceutical Co. Ltd., India.

*Corresponding Author's E-mail: kanth.maddela@gmail.com

\begin{abstract}
A regulatory process, by which a person/organization/sponsor/innovator gets authorization to launch a drug in the market, is known as drug approval process. The United States - Food and Drug Administration (U.S. FDA) has its own regulatory strategy to approve and allow generic drugs in to the market, which is named as Generic Drug Submission Review. FDA would like to slash the review time of generic drug application without compromising the quality and efficacy of proposed generic drugs for the intended use and to make them available to consumers in short time as possible. FDA has introduced Generic Drug User Fee program to supplement appropriate funding for resource management to ensure that consumers continue to receive the significant benefits offered by generic drugs. The purpose of this article is to present a concise overview about Generic Drug User Fee program and the recent advances in Abbreviated New Drug Application (ANDA) review process.
\end{abstract}

Keywords: FDA, FDASIA, ANDA, GDUFA, Generic Drug Submission.

\section{INTRODUCTION}

A generic drug is a drug defined as "a drug product that is comparable to brand/reference listed drug product in dosage form, strength, route of administration, quality, performance characteristics, and intended use". (1) It has also been defined as a term referring to any drug marketed under its chemical name without advertising. For most of the consumers, generic drugs are important options that allow greater access to get health care in economical way compared to branded drugs. The generic drugs are nothing but the copies of brand-name drugs and are therapeutically equivalent to brand drugs. (2)

Since 1984, the Food and Drug Administration (FDA) has approved more than 8,000 generic equivalents of brand-name drugs. Generic drugs typically costs 50 to 70 percent less than their brand-name counterparts, resulting in cost savings for consumers and the U.S. Nation's health care system. In the year 2011, approximately 78 percent of the more than three billion new and refilled outpatient prescriptions dispensed in the United States were filled with generics. In the last decade alone, generic drugs have provided more than $\$ 824$ billion in savings to the U.S. Nation's health care system. (3) Recognizing the critical role that generic drugs play in providing more affordable, therapeutically equivalent medicine, FDA would like to slash the review time of generic drug application without compromising the quality and efficacy of generic drugs for the intended use and to make available to consumers in short time as possible. In order to bring the generic drugs more and more into the market in short time through effective review process, FDA has introduced Generic Drug User Fee program to supplement appropriated funding for resource management to ensure that consumers continue to receive the significant benefits offered by generic drugs.

\section{GENERIC DRUG APPROVAL PROCESS}

In general to get marketing approval for a generic drug from U.S. Food and Drug Administration include various junctures such as finding basis for submission, getting drug substances from approved DMF vendors, finished product development, clinical /bioequivalence-bioavailability studies, plant inspection, dossier writing and finally submission to authorities. The diagram (Figure 
1) illustrates the various elements involved in product. (4) obtaining regulatory approval for generic

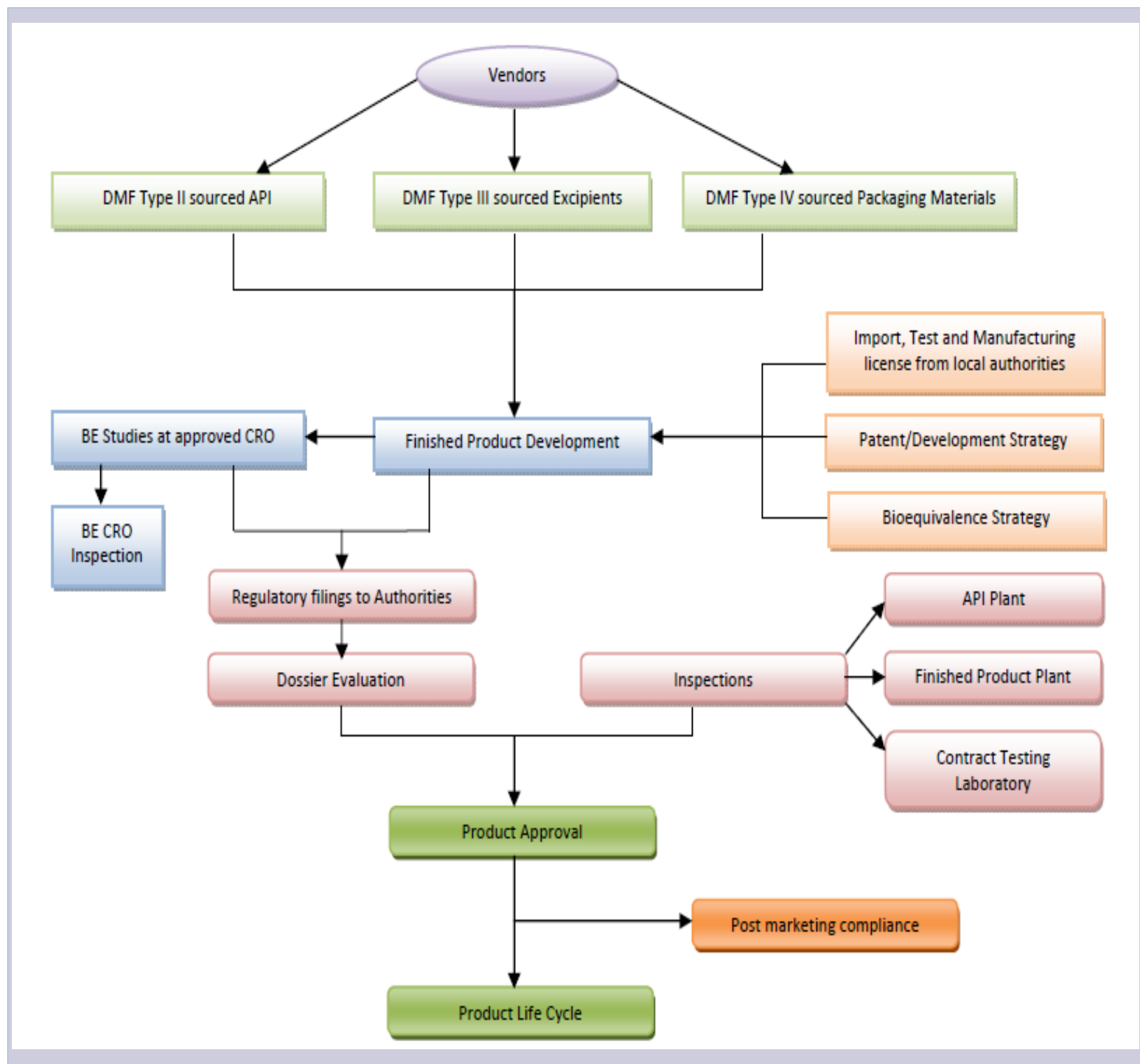

\section{Figure 1. Components involved in obtaining regulatory approval}

\section{for generic product}

The review of generic product application will be initiated after submission of dossier to the regulatory authority. During review, if any deficiency arises generic applicant must be ready to provide responses with scientific rationales. Upon completion of scientific review of the application and after arriving to a conclusion that the submitted generic application is therapeutically equivalent to the reference listed drug upon which the generic application was based, agency will issue an approval letter for the generic product to introduce in to the market.

In Generic Drug Submission Review (5) the general responsibilities of the agency's designee and detailed activities are as follows:

Table 1: General Responsibilities

(a) Review of the Generic submission.

(b) Inspection of Facilities associated with the generic drugs.

(c) Product lifecycle monitoring 
Table 2: Detailed Activities

\begin{tabular}{|l|l|}
\hline (a) & $\begin{array}{l}\text { Review of generic drug submissions, including review of drug master files referenced in such } \\
\text { submissions. }\end{array}$ \\
\hline (b) & $\begin{array}{l}\text { Issuance of letters for related generic drug submissions- } \\
\text { i. Approval letters for abbreviated new drug applications or supplements to such applications } \\
\text { ii. Complete response letters with in detailed specific deficiencies, and where appropriate the } \\
\text { actions necessary to place such applications in condition for approval. }\end{array}$ \\
\hline (c) & $\begin{array}{l}\text { Issuance of letters related to Type II active pharmaceutical drug master files- } \\
\text { actters with in detailed specific deficiencies in such submissions, and where appropriate, the } \\
\text { ii. The document that no deficiencies need to be addressed. }\end{array}$ \\
\hline (d) & $\begin{array}{l}\text { Inspections related to generic drugs. } \\
\text { (e) }\end{array}$ \\
\hline $\begin{array}{l}\text { Monitoring of research conducted in connection with the review of generic drug submissions } \\
\text { and drug master files. }\end{array}$ \\
$\begin{array}{l}\text { Monitoring post-market safety activities with respect to drugs approved under abbreviated new } \\
\text { drug applications or supplements, including the following: } \\
\text { i. Collecting, developing, and reviewing safety information on approved drugs, including } \\
\text { adverse event reports (AERs). } \\
\text { ii. Developing and using improved adverse-event data-collection systems, including } \\
\text { information technology systems. } \\
\text { iii.Developing and using improved analytical tools to assess potential safety problems, } \\
\text { including access to external data bases. } \\
\text { iv. Implementing and enforcing section 505(o) (relating to post approval studies and clinical } \\
\text { trials and labeling changes) and section 505(p) (relating to risk evaluation and mitigation } \\
\text { strategies) insofar as those activities relate to abbreviated new drug applications. } \\
\text { v. Carrying out section 505(k)(5) (relating to adverse-event reports and post market safety } \\
\text { activities). }\end{array}$ \\
\hline (g) Regulatory science activities related to generic drugs. \\
(f)
\end{tabular}

In order to complete the review of generic applications more significantly faster and to make the generic drugs available to patients quickly, congress has introduced an act popularly known as Food and Drug Administration Safety and Innovation Act (FDASIA) by giving authorities to U.S. FDA to collect user fee for generic drugs applications through Generic Drug User Fee program. This designed Generic Drug User Fee program is expected to provide significant value to small companies and first time entrants in the generic market who will get benefit significantly from

Table 3: Expanded FDA's Authorities associated performance review metrics that offer the potential to dramatically reduce the time needed to commercialize a generic drug when compared to pre-GDUFA review times.

\section{FOOD AND DRUG ADMINISTRATION SAFETY AND INNOVATION ACT (FDASIA) (5)}

The Food and Drug Administration Safety and Innovation Act (FDASIA), signed into law on July 9, 2012; expands the FDA's authorities and strengthens the agency's ability to safeguard and advance public health by:

\begin{tabular}{|l|l|}
\hline (a) & $\begin{array}{l}\text { Giving the authority to collect user fees from industry to fund reviews of innovator drugs, } \\
\text { medical devices, generic drugs and biosimilar biological products. }\end{array}$ \\
\hline (b) & Promoting innovation to speed patient access to safe and effective products. \\
\hline (c) & Increasing stakeholder involvement in FDA processes. \\
\hline (d) & Enhancing the safety of the drug supply chain. \\
\hline
\end{tabular}


Table 4: FDASIA Table of Contents

\begin{tabular}{|l|l|}
\hline TITLE I & Fees relating to Drugs \\
\hline TITLE II & Fees relating to Devices \\
\hline TITLE III & Fees relating to Generic Drugs \\
\hline TITLE IV & Fees relating to Biosimilar Biological Products \\
\hline TITLE V & Pediatric Drugs and Devices \\
\hline TITLE VI & Medical device regulatory improvements \\
\hline TITLE VII & Drug Supply Chain \\
\hline TITLE VIII & Generating Antibiotic Incentives now \\
\hline TITLE IX & Drug approval and Patient access \\
\hline TITLE X & Drug Shortages \\
\hline TITLE XI & Other Provisions \\
\hline
\end{tabular}

Table 5: User fee established for

\begin{tabular}{|l|l|}
\hline (a) & $\begin{array}{l}\text { Certain applications in the backlog as of October 1, } 2012 \text { (only applicable to financial year } \\
\text { (FY) 2013). }\end{array}$ \\
\hline (b) & Certain types of applications and supplements associated with human generic drug products. \\
\hline (c) & Certain facilities where APIs and FDFs are produced. \\
\hline (d) & Certain type II API DMFs associated with human generic drug products. \\
\hline
\end{tabular}

The Food and Drug Administration Safety and Innovation Act (FDASIA) has been designed including the following parts under different titles:

Under sections 744A and744B of the FD\&C Act (21 U.S.C. $379 \mathrm{j}-41$ and $379 \mathrm{j}-42$ ), as added by GDUFA [in Title III of the Food and Drug Administration Safety and Innovation Act (Public Law 112-144), which was signed by the President on July 9, 2012], and as further amended by the FDA User Fee Correction Act of 2012 (Public Law 112-193) (signed by the President on October 5, 2012), user fee have been established for the following which are associated with human generic drug product submission.

\section{GENERIC DRUG USER FEE AMENDMENTS OF 2012 (GDUFA) (5)}

GDUFA (Public Law 112-144, Title III) was signed into law by the President of United States on July 09, 2012. GDUFA was designed to speed the delivery of safe and effective generic drugs to the public and reduce costs to industry.
GDUFA enables FDA to assess user fees to support critical and measurable enhancements to FDA's generic drugs program.

This legislation has been brought by FDA at a critical time. The public health success of generic drugs has also created a significant challenge. In pre-GDUFA time due to limited resources, FDA was not able to keep pace with an increasing number of applications requiring review. There were about more than 2,500 applications for new generic drugs seeking approval by the year 2012. However, with the enactment of the Generic Drug User Fee Amendments of 2012 (GDUFA), for the first time ever, FDA receives funding from the generic drug industry to ensure the timely access to safe, high-quality, and effective generic drugs. Further, with received funding additional resources will be allocated by the agency to reduce the backlog of pending applications, to slash the average time required to review generic drug applications without compromising the review quality and also increasing the riskbased inspections in order to bring the generic 
drugs into the market and to the patients more quickly.

For the purpose of the designed FDASIA and GDUFA program the following definitions have been considered for few important terms being used in the Act:

\section{Abbreviated new drug application (ANDA)}

An application submitted under section 505(j), an abbreviated application submitted under section 507 (as in effect on the day before the date of enactment of the Food and Drug Administration Modernization Act of 1997), or an abbreviated new drug application submitted pursuant to regulations in effect prior to the implementation of the Drug Price Competition and Patent Term Restoration Act of 1984; and does not include an application for a positron emission tomography drug.

\section{Active pharmaceutical ingredient (API)}

A substance, or a mixture when the substance is unstable or cannot be transported on its own, intended

(i) to be used as a component of a drug; and (ii) to furnish pharmacological activity or other direct effect in the diagnosis, cure, mitigation, treatment, or prevention of disease, or to affect the structure or any function of the human body; or

A substance intended for final crystallization, purification, or salt formation, or any combination of those activities, to become a substance or mixture described in above paragraph.

\section{Finished dosage form (FDF)}

A drug product in the form in which it will be administered to a patient, such as a tablet, capsule, solution, or topical application;

A drug product in a form in which reconstitution is necessary prior to administration to a patient, such as oral suspensions or lyophilized powders; or

Any combination of an active pharmaceutical ingredient with another component of a drug product for purposes of production of a drug product described in above two paragraphs.

\section{Facility}

A business or other entity (i) under one management, either direct or indirect; and (ii) at one geographic location or address engaged in manufacturing or processing an active pharmaceutical ingredient or a finished dosage form; and does not include a business or

Other entity whose only manufacturing or processing activities are one or more of the following: repackaging, relabeling, or testing.

\section{Generic drug submission}

It means, an abbreviated new drug application, an amendment to an abbreviated new drug application, or a prior approval supplement to an abbreviated new drug application.

\section{Type II active pharmaceutical ingredient drug master file}

It means, a submission of information to the agency by a person that intends to authorize the Food and Drug Administration to refer the information to support the approval of a generic drug submission without the submitter having to disclose the information to the generic applicant.

\section{Pending Application}

The original ANDA that has not been withdrawn or tentatively approved or approved by September 28, 2012.

\section{Solicited Amendment}

A submission made by an applicant in response to a complete response letter (CR) issued by FDA. Solicited amendments are classified as either Tier 1 or Tier 3.

\section{Major Amendment}

Major amendments contain a substantial amount of new data or new information not previously submitted to or reviewed by FDA, requiring, in FDA's judgment, a substantial expenditure of FDA resources. The first solicited major amendment is classified as Tier 1; any solicited major amendment subsequent to the first is classified as Tier 3.

\section{Minor Amendment}


FDA review of a minor amendment requires, in FDA's judgment, fewer FDA resources than are necessary to review a major amendment, but more than are necessary to review the information submitted in response to an ECD. The first through fifth solicited minor amendment are classified as Tier 1; any solicited minor amendment subsequent to the fifth minor amendment is classified as Tier 3 .

\section{Easily Correctable Deficiency (ECD)}

FDA review of information submitted in response to an ECD requires, in FDA's judgment, a modest expenditure of FDA resources.

\section{Unsolicited Amendment}

A submission made by an applicant on their own initiative and not in response to FDA's CR letter. Unsolicited amendments are categorized as either delaying or non-delaying. All delaying unsolicited amendments are classified as Tier 1 amendments. All non-delaying unsolicited amendments are classified as Tier 2 amendments.

\section{Delaying Amendment}

Delaying amendments address actions by a third party that would cause delay or impede application review or approval timing and that were not a factor at the time of submission. Unsolicited amendments that are in response to a delaying action or that FDA would eventually solicit are classified as Tier 1 delaying amendments. Delaying amendments do not add to the count of major or minor amendments for the purpose of classification.

\section{Non-delaying Amendment}

Non-delaying amendments are unsolicited amendments that contain information that is not requested by FDA and is not the result of changes to the RLD or USP monograph, changes to the RLD labeling, a REMS and REMS modification, or generic approval requirements reflected in citizen petition responses issued by FDA.

\section{Administrative Amendment}

Administrative amendments are routine in nature and do not require scientific review. Requests for final approval with no scientific changes to the ANDA, patent amendments, and general correspondence submitted by applicants are generally considered administrative amendments. Administrative amendments do not affect the goal dates for the application and, as a result, are considered neither Tier 1, Tier 2, nor Tier 3 amendments.

\section{GDUFA GOALS \& TARGETS $(3,5)$}

GDUFA is five year program with the goal of self fund generation, establishing a hiring authority for all GDFA-related positions, building and maintaining new data bases as necessary for facilities, fee assessments in collaboration with Industry. This five year GDUFA plan has been subdivided into cohort 1 to cohort 5 considering each financial year as one cohort. The summary of FDA's commitments phase-in over the five year period is presented below:

Table 6: Commitment phase-in over the five year period

\begin{tabular}{|c|c|c|c|c|c|}
\hline & FY 2013 & FY 2014 & FY 2015 & FY 2016 & FY 2017 \\
\hline Hire and train new staff & $25 \%$ of total & $50 \%$ of total & $25 \%$ of total & & \\
\hline $\begin{array}{l}\text { Type II DMF completeness } \\
\text { assessment - conduct and publish } \\
\text { list }\end{array}$ & & & & & \\
\hline $\begin{array}{l}\text { Enhances refuse to receive } \\
\text { standards for ANDAs and related } \\
\text { submissions }\end{array}$ & & & & & \\
\hline Respond to appeals for ANDAs & Within $30 \mathrm{da}$ & s of receipt & & & \\
\hline ANDA teleconference requests & & & $\begin{array}{l}\text { Close-out } \\
200\end{array}$ & $\begin{array}{l}\text { Close- } \\
\text { out } 250\end{array}$ & $\begin{array}{l}\text { Close-out } \\
300\end{array}$ \\
\hline
\end{tabular}




\section{Type II DMF teleconference requests}

Risk-adjusted biennial cGMP surveillance inspections of generic API and generic finished dosage form manufacturers
Limit one per DMF holder per month not to exceed ANDA teleconference levels

Table 7: New classification of Amendments under GDUFA

\begin{tabular}{|l|l|l|}
\hline & Solicited Amendment Goals & Unsolicited Amendment Goals \\
\hline Tier 1 & $\begin{array}{l}\text { 1st Major: 10 months } \\
\text { 1st }- \text { 3rd Minor: 3 months* } \\
\text { 4th }- \text { 5th Minor: 6 months* }\end{array}$ & $\begin{array}{l}\text { Delaying action or otherwise would eventually be } \\
\text { solicited: 3 months* }\end{array}$ \\
\hline Tier 2 & N/A & $\begin{array}{l}\text { Amendment not arising from “delaying action": } \\
12 \text { months }\end{array}$ \\
\hline Tier 3 & $\begin{array}{l}\geq \text { 2nd Major: No goal } \\
\geq 6 \text { th Minor: No goal }\end{array}$ & N/A \\
\hline$* 10$ months if inspection required
\end{tabular}

Table 8: Targeted performance goals in five years of GDUFA program (apply only to electronic submissions)

\begin{tabular}{|c|c|c|c|c|}
\hline Submission type & FY 2013 FY 2014 & FY 2015 & FY 2016 & FY 2017 \\
\hline Original ANDA & \begin{tabular}{lrr}
\multicolumn{2}{|l}{ Expedites } & review of \\
paragraph IV & and \\
maintain & pre- \\
GDUFA & \\
productivity & \\
\end{tabular} & $\begin{array}{l}60 \% \text { in } 15 \\
\text { months }\end{array}$ & $\begin{array}{l}75 \% \text { in } 15 \\
\text { months }\end{array}$ & $\begin{array}{l}90 \% \text { in } 10 \\
\text { months }\end{array}$ \\
\hline Tier 1 fist major amendment & $\begin{array}{ll}\text { Maintain } & \text { pre- } \\
\text { GDUFA } & \\
\text { productivity } & \\
\end{array}$ & $\begin{array}{l}60 \% \text { in } 10 \\
\text { months }\end{array}$ & $\begin{array}{l}75 \% \text { in } 10 \\
\text { months }\end{array}$ & $\begin{array}{l}90 \% \text { in } 10 \\
\text { months }\end{array}$ \\
\hline Tier 1 major amendments $\left(1^{\text {st }}\right.$ to $\left.3^{\text {rd }}\right)$ & $\begin{array}{l}\text { Maintain } \\
\text { GDUFA } \\
\text { productivity } \\
\end{array}$ & $\begin{array}{l}60 \% \text { in } 3 \\
\text { months* }\end{array}$ & $\begin{array}{l}75 \% \text { in } 3 \\
\text { months* }\end{array}$ & $\begin{array}{l}90 \% \text { in } 3 \\
\text { months* }\end{array}$ \\
\hline Tier 1 major amendments $\left(4^{\text {th }}\right.$ to $\left.5^{\text {th }}\right)$ & $\begin{array}{l}\text { Maintain } \\
\text { GDUFA } \\
\text { productivity } \\
\end{array}$ & $\begin{array}{l}60 \% \text { in } 6 \\
\text { months* }\end{array}$ & $\begin{array}{l}75 \% \text { in } 6 \\
\text { months* }\end{array}$ & $\begin{array}{l}90 \% \text { in } 6 \\
\text { months* }\end{array}$ \\
\hline Tier 2 amendment & $\begin{array}{l}\text { Maintain } \\
\text { GDUFA } \\
\text { productivity } \\
\end{array}$ & $\begin{array}{l}60 \% \text { in } 12 \\
\text { months* }\end{array}$ & $\begin{array}{l}75 \% \text { in } 12 \\
\text { months* }\end{array}$ & $\begin{array}{l}90 \% \text { in } 12 \\
\text { months* }\end{array}$ \\
\hline Prior approval supplements & $\begin{array}{ll}\text { Maintain } & \text { pre- } \\
\text { GDUFA } & \\
\text { productivity } & \\
\end{array}$ & $\begin{array}{l}60 \% \text { in } 6 \\
\text { months* }\end{array}$ & $\begin{array}{l}75 \% \text { in } 6 \\
\text { months* }\end{array}$ & $\begin{array}{l}90 \% \text { in } 6 \\
\text { months* }\end{array}$ \\
\hline $\begin{array}{l}\text { ANDA amendment, and PAS in } \\
\text { backlog on October } 1^{\text {st }}, 2012\end{array}$ & \multicolumn{4}{|c|}{ Act on $90 \%$ by end of FY 2017} \\
\hline Controlled correspondences & $\begin{array}{l}\text { Maintain pre-GDUFA } \\
\text { productivity }\end{array}$ & $\begin{array}{l}70 \% \text { in } \\
\text { months } * *\end{array}$ & $4 \mid \begin{array}{l}70 \% \text { in } \\
\text { months: }\end{array}$ & \begin{tabular}{r|l}
2 & $\begin{array}{l}70 \% \\
\text { in 2 } \\
\text { month } \\
\mathrm{s}^{* *}\end{array}$
\end{tabular} \\
\hline
\end{tabular}


*10 months if inspection required

** One additional month added to goal if clinical division input required

Table 9: Types of User Fee that FDA authorized to collect

\begin{tabular}{|l|l|}
\hline (a) & $\begin{array}{l}\text { One time Backlog Fee for pending abbreviated new drug applications (only applicable to } \\
\text { financial year (FY) 2013). }\end{array}$ \\
\hline (b) & Drug Master File Fee. \\
\hline (c) & Abbreviated New Drug Application and Prior Approval Supplement Filing Fee. \\
\hline (d) & Generic Drug (FDF) Facility Fee and Active Pharmaceutical Ingredient Facility Fee. \\
\hline
\end{tabular}

Table 10: Summary of User Fee details since FY 2013 to FY 2015 under GDUFA

\begin{tabular}{|c|c|c|c|c|c|}
\hline Fee Type & Who incurs the Fee? & $\begin{array}{l}\text { Payment } \\
\text { frequency }\end{array}$ & FY 2013 & FY 2014 & FY 2015 \\
\hline Backlog Fee & $\begin{array}{l}\text { An applicant whose original } \\
\text { ANDA was pending on Oct. } \\
1,2012 \text { without a tentative } \\
\text { approval }\end{array}$ & Once & $\$ 17,434$ & NA & NA \\
\hline DMF Fee & $\begin{array}{l}\text { A Type II active } \\
\text { pharmaceutical ingredient } \\
\text { (API) DMF holder whose } \\
\text { DMF is referenced by an } \\
\text { initial letter of authorization in } \\
\text { a generic drug submission on } \\
\text { or after Oct. 1, 2012 }\end{array}$ & $\begin{array}{l}\text { Once for } \\
\text { each API } \\
\text { DMF, no } \\
\text { later than } \\
\text { when first } \\
\text { letter of } \\
\text { authorization } \\
\text { is submitted }\end{array}$ & $\$ 21,340$ & $\$ 31,460$ & $\$ 26,720$ \\
\hline $\begin{array}{l}\text { ANDA Fee, } \\
\text { and } \\
\text { PAS Fee }\end{array}$ & $\begin{array}{l}\text { An applicant submitting an } \\
\text { ANDA or PAS on or after } \\
\text { October } 01,2012\end{array}$ & $\begin{array}{l}\text { Once at the } \\
\text { time of } \\
\text { ANDA or } \\
\text { PAS } \\
\text { submission }\end{array}$ & $\begin{array}{c}\text { ANDA: } \\
\$ 51,520 \\
\text { PAS: } \\
\$ 25,760\end{array}$ & $\begin{array}{c}\text { ANDA: } \\
\$ 63,860 \\
\text { PAS: } \\
\$ 31,930\end{array}$ & $\begin{array}{c}\text { ANDA: } \\
\$ 58,730 \\
\\
\text { PAS: } \\
\$ 29,370 \\
\end{array}$ \\
\hline $\begin{array}{l}\text { Facility } \\
\text { Fees for } \\
\text { API and } \\
\text { FDF }\end{array}$ & $\begin{array}{l}\text { The owner of a facility } \\
\text { identified, or intended to be } \\
\text { identified, in at least one } \\
\text { generic drug submission that } \\
\text { is pending or approved to } \\
\text { produce one or more generic } \\
\text { drug finished dosage form } \\
\text { (FDF) and/or APIs. }\end{array}$ & Annually & $\begin{array}{l}\text { API: } \\
\text { Domesti } \\
\text { c } \\
\$ 26,458 \\
\text { Foreign } \\
\$ 41,458 \\
\text { FDF: } \\
\text { Domestic } \\
\text { \$175,389 } \\
\text { Foreign } \\
\$ 190,389\end{array}$ & $\begin{array}{l}\text { API: } \\
\text { Domestic } \\
\$ 34,515 \\
\text { Foreign } \\
\$ 49,515 \\
\text { FDF: } \\
\text { Domestic } \\
\text { \$220,152 } \\
\text { Foreign } \\
\$ 235,152\end{array}$ & $\begin{array}{l}\text { API: } \\
\text { Domesti } \\
\text { c } \\
\$ 41,926 \\
\text { Foreign } \\
\$ 56,926 \\
\\
\text { FDF: } \\
\text { Domesti } \\
\text { c } \\
\$ 247,71 \\
7 \\
\text { Foreign } \\
\$ 262,71 \\
7\end{array}$ \\
\hline
\end{tabular}

In accordance with the commitment letter (3), FDA agreed to certain performance goals and procedures for the review of amendments submitted electronically to original ANDAs and 
PASs filed on or after October 1, 2014. The performance goals do not apply to amendments submitted on or after October 1, 2014, if they amend original ANDAs or PASs submitted before October 1, 2014. For purposes of FDA's performance goals, FDA has classified the amendment into different Tiers with different goal date for completion of review. Each Tier has corresponding performance metric goals, ranging from a 3-month review clock to no goal date, depending on the amendment's classification.

\section{USER FEE DETAILS UNDER GDUFA $(5,6)$}

The Federal Food, Drug, and Cosmetic Act (FD\&C Act), as amended by the Generic Drug User Fee Amendments of 2012 (GDUFA), as further amended by the FDA User Fee Correction Act of 2012, authorizes FDA to assess and collect user fees for the following:

The detailed information presented as follows:

\section{One-time Backlog Fee for pending abbreviated new drug applications (7-9)}

Under GDUFA, each person that owns an abbreviated new drug application that is pending on October 1, 2012, and that has not received a tentative approval prior to that date, were subjected to a backlog fee for each such application (section 744B(a)(1)(A) of the FD\&C Act). The backlog fee has been assessed one time only, for financial year (FY) 2013, and no backlog fee was assessed in subsequent years.

Under section 744B(a)(1)(B) of the FD\&C Act, the backlog fee has been calculated by taking the exact number of pending abbreviated new drug applications in the backlog that have not received tentative approval as of October 1, 2012. The established backlog fee was $\mathbf{\$ 1 7 , 4 3 4}$ only for financial year (FY) 2013.
For financial year (FY) 2013, the backlog fee for each pending application was due on November 26, 2012 i.e., within 30 days after publication of (section 744B(a)(1)(D) of the FD\&C Act) Federal Register Notice dated October 25, 2012.

The person that owns an original ANDA that fail to pay the backlog fee has been placed on publicly available arrears list, and FDA has not received a new ANDA or supplement submitted by that person, or any affiliate of that person, within the meaning of $505(\mathrm{j})(5)(\mathrm{A})$ of the Federal Food, Drug and Cosmetic Act, until the outstanding fee paid.

FDA has also published a notice for the benefit of generic manufacturers saying that those generic manufacturers who no longer seeking approval of their application can withdraw their pending application before September 28, 2012 to avoid paying a fee.

\section{Drug Master File Fee (9-12)}

Under GDUFA, the DMF fee was owed by each person that owns a type II active pharmaceutical ingredient drug master file that was referenced, on or after October 1, 2012, in a generic drug submission by an initial letter of authorization.

This is a one-time fee for each individual DMF. If a person has paid a drug master file fee for a Type II active pharmaceutical ingredient drug master file, the person shall not be required to pay a subsequent drug master file fee when that Type II active pharmaceutical ingredient drug master file is subsequently referenced in generic drug submissions.

Based on the number of DMFs referenced to ANDAs and PASs every year, FDA has estimated to collect the DMF fee in FY 2013, 2014 \& 2015 as follows:

Table 11: Details of DMF Submission fee

\begin{tabular}{|c|c|}
\hline Fiscal Year & DMF Fee (USD) \\
\hline 2013 & 21,340 \\
\hline 2014 & 31,460 \\
\hline 2015 & 26,720 \\
\hline
\end{tabular}

The established Fee for financial year (FY) $2015 \quad$ Fees for financial years (FYs) 2015-2017 will be will remain effect through September 30, 2015. adjusted for inflation and other factors, 
including the projected number of DMFs that FDA expects to be referenced for the first time in a given year based on experience. The fees details will be published in Federal Register no later than 60 days before the start of each fiscal year (October $1^{\text {st }}$ to September $30^{\text {th }}$ ).

DMF fees will be incurred at the time of submission of a generic drug submission for all Type II API DMFs referenced for the first time by an initial letter of authorization on or after October 1, 2012. In general, fees will be due on the date the first generic drug submission is submitted that references the associated type II API DMF.

DMF holders may also pay the fee in advance of a first reference in order to have their DMF subjected to an initial completeness assessment by the Agency. This would allow their DMF to be included on a publicly-available list of DMFs that have paid their fee and not failed in the initial completeness assessment.

GDUFA requires Type II API DMFs to undergo initial complete assessment (CA) to ensure that the DMF is complete. (13) Although the requirement for an initial CA for Type II API DMFs is new, the elements of the initial CA have been used previously by FDA to evaluate DMFs. DMFs that have paid the fee and been found to be complete in accordance with the criteria for an initial CA set out in the checklist of guidance will be identified on FDA's public web site as available for reference in support of a generic drug submission. This initial CA does not replace the full scientific review, which will be performed to determine the adequacy or inadequacy of the information contained in the DMF to support an ANDA review decision.

For a generic drug submission to reference a Type II active pharmaceutical ingredient drug master file, the drug master file must be deemed available for reference in the Agency's website. A drug master file shall be deemed available for reference if:

(a) The person that owns a Type II active pharmaceutical ingredient drug master file must pay the DMF fee as required under GDUFA. (b) The drug master file has not failed initial completeness assessment by the reviewer, in accordance with criteria set forth in the guidance.

If above criteria (a) and (b) were met, then the DMF will be made publicly available on the Internet web site of the Food and Drug Administration in the list of drug master file numbers available for reference.

If DMF holder failed to pay the DMF Fee then the DMF will be deemed not available for reference. Once the DMF fee becomes due, no generic drug submission submitted on or after October 1, 2012, referencing the DMF will not be received unless the fee is paid and the DMF is deemed available for reference.

\section{Abbreviated New Drug Application and Prior Approval Supplement Filing Fee (9-12)}

Under GDUFA, each applicant that submits, an abbreviated new drug application or a prior approval supplement to an abbreviated new drug application on or after October 1, 2012 shall be subjected to a fee for each such submission.

These fees are due on the date of submission of the ANDA or PAS. In certain circumstances, a partial refund (75 percent of the fee paid) may be possible to the applicant, if the reason for refusal of application is not related to failure to pay fees.

Based on the number of ANDAs and PASs received in each FY year, FDA has estimated to collect the ANDA and PAS fee in FY 2013, 2014 \& 2015 as follows:

The established Fee for financial year (FY) 2015 will remain effect through September 30, 2015. Fees for financial years (FYs) 2015-2017 will be adjusted for inflation and other factors, including the projected number of ANDAs \& PASs that FDA expects in a given year based on experience. The fees details will be published in Federal Register no later than 60 days before the start of each fiscal year (October $1^{\text {st }}$ to September $30^{\text {th }}$ ).

If ANDA sponsor failed to pay either ANDA or PAS fee within 20 calendar days of from the date of submission, those submission will not be received by the Agency. (14) 
Table 12: Details of ANDA and PAS submission fee

\begin{tabular}{|c|c|c|}
\hline Fiscal Year & ANDA Fee (USD) & PAS Fee (USD) \\
\hline 2013 & 51,520 & 25,760 \\
\hline 2014 & 63,860 & 31,930 \\
\hline 2015 & 58,730 & 29,370 \\
\hline
\end{tabular}

Table 13: Types of facilities

\begin{tabular}{|l|l|}
\hline Feneric Drug & $\begin{array}{l}\text { Each person that owns a facility which is identified or intended to be identified } \\
\text { in at least one generic drug submission that is pending or approved to produce } \\
\text { one or more finished dosage forms of a human generic drug shall be assessed an } \\
\text { annual fee for each such facility. }\end{array}$ \\
\hline API Facility & $\begin{array}{l}\text { Each person that owns a facility which produces, or which is pending review to } \\
\text { produce, one or more active pharmaceutical ingredients identified, or intended to } \\
\text { be identified, in at least one generic drug submission that is pending or approved } \\
\text { or in a Type II active pharmaceutical ingredient drug master file referenced in } \\
\text { such a generic drug submission, shall be assessed an annual fee for each such } \\
\text { facility. }\end{array}$ \\
\hline $\begin{array}{l}\text { Facilities } \\
\text { producing both } \\
\text { APIs and FDF }\end{array}$ & $\begin{array}{l}\text { Each person that owns a facility identified, or intended to be identified, in at } \\
\text { least one generic drug submission that is pending or approved to produce both } \\
\text { one or more finished dosage forms subject to above referred Generic Drug } \\
\text { Feferred API facility shall be subject to fees under both such clauses for that } \\
\text { facility. }\end{array}$ \\
\hline
\end{tabular}

An abbreviated new drug application or prior approval supplement that was submitted on or after October 1, 2012, and that the agency considers not to have been received, or that has been withdrawn, shall, upon resubmission of the application or a subsequent new submission following the applicant's withdrawal of the application, be subject to a full fee in respective Financial year of submission as per GDUFA Program.

Those ANDAs that include information about the production of active pharmaceutical ingredients other than by reference to a DMF need to pay an additional fee (i.e., DMF fee) that is based on the number of such active pharmaceutical ingredients and the number of facilities proposed to produce those ingredients.

\section{Generic drug facility fee and active pharmaceutical ingredient facility fee $(5,9)$}

Facilities identified, or intended to be identified, in at least one generic drug submission that is pending or approved to produce a finished dosage form (FDF) of a human generic drug or an active pharmaceutical ingredient (API) contained in a human generic drug shall be subject to fees as follows:

In order to calculate the Annual FDF and API facility fee, FDA has designed a unique process called "self identification" of facilities in order to populate total number of facilities in one database. In this database the facilities will be categorized based on the type of business operations. Thus self identified number of 
facilities will be considered for deciding the Facility fee for that financial year.

\section{Self identification of facilities and laboratories $(11,12,15-18)$}

The Food and Drug Administration (FDA) has notified generic drug facilities, and certain sites

Table 14: Details of Self identification Process and organizations identified in a generic drug submission, that they must provide identification information to FDA. This information is required to be submitted to the FDA annually under the Generic Drug User Fee Act Amendments of 2012 (GDUFA) included in the Food and Drug Administration Safety and Innovation Act (FDASIA).

\begin{tabular}{|c|c|c|}
\hline $\begin{array}{l}\text { Who is } \\
\text { required to } \\
\text { self-identify? }\end{array}$ & $\begin{array}{l}\text { API, or bo } \\
\text { (b) A site or } \\
\text { more of th } \\
\text { - A site in } \\
\text { - A clinica } \\
\text { - A contra } \\
\text { - A contra }\end{array}$ & $\begin{array}{l}\text { d, or intended to be identified, in at least one generic drug } \\
\text { pending or approved to produce a human generic FDF or } \\
\text { tion identified in a generic drug submission that is one or } \\
\text { ing: } \\
\text { bioanalytical study is conducted } \\
\text { h organization } \\
\text { ical testing site } \\
\text { kager site }\end{array}$ \\
\hline $\begin{array}{l}\text { What type of } \\
\text { information } \\
\text { must be } \\
\text { submitted? }\end{array}$ & $\begin{array}{l}\text { The informati } \\
\text { Technical Spe } \\
\text { In brief the fo } \\
\text { (a) Name and } \\
\text { if they are } \\
\text { (b) Type of bi } \\
\text { (c) Data Univ } \\
\text { unique nin } \\
\text { (d) Facility E } \\
\text { by FDA tc } \\
\text { (e) Business } \\
\text { generics. }\end{array}$ & $\begin{array}{l}\text { red to be submitted is identified in GDUFA SPL Industry } \\
\mathrm{n} \text { Information document available at www.fda.gov/gdufa. } \\
\text { information is required to submit: } \\
\text { information for both the registrant owner and the facility, } \\
\text { t, must be submitted. } \\
\text { peration } \\
\text { mbering System (DUNS) number(s) - DUNS number is a } \\
\text { equence provided by Dun \& Bradstreet, Inc. } \\
\text { tent Identifier (FEI) - FEI is a unique identifier designated } \\
\text { monitor, and track inspections of regulated firms. } \\
\text { will also be asked if they manufacture drugs other than }\end{array}$ \\
\hline \multirow{6}{*}{$\begin{array}{lr}\text { Time } & \text { period } \\
\text { for } & \text { self } \\
\text { identification }\end{array}$} & Fiscal Year & $\begin{array}{l}\text { Self -Identification submissions received during the } \\
\text { following dates }\end{array}$ \\
\hline & 2013 & Oct. 1, 2012 - Dec. 3, 2012 \\
\hline & 2014 & May 1, 2013 - June 1, 2013 \\
\hline & 2015 & May 1, 2014 - June 1, 2014 \\
\hline & 2016 & May 1, 2015 - June 1, 2015 \\
\hline & 2017 & May 1, 2016 - June 1, 2016 \\
\hline $\begin{array}{l}\text { What is the } \\
\text { penalty for } \\
\text { failing to self- } \\
\text { identify? }\end{array}$ & \multicolumn{2}{|c|}{$\begin{array}{l}\text { (a) Under GDUFA, if a facility fails to self-identify, all FDF or API products } \\
\text { manufactured at the facility and all FDFs containing APIs manufactured at } \\
\text { the facility will be deemed misbranded. } \\
\text { (b) It is a violation of Federal law to ship misbranded products in interstate } \\
\text { commerce or to import them into the United States. Such a violation can } \\
\text { result in prosecution of those responsible, injunctions, or seizures of the } \\
\text { misbranded products. } \\
\text { (c) Products that are deemed misbranded because of failure of the facility to self- } \\
\text { identify are subject to being denied entry into the United States. }\end{array}$} \\
\hline $\begin{array}{l}\text { Which } \\
\text { acilities have }\end{array}$ & \multicolumn{2}{|c|}{$\begin{array}{l}\text { Facilities identified, or intended to be identified, in at least one generic drug } \\
\text { submission that is pending or approved to produce a human generic } \boldsymbol{F D F} \text { or }\end{array}$} \\
\hline
\end{tabular}


to pay the API, or both.

facility fee?

Based on the collated data of facilities (API and FDF) from self identification process the facility fee has been decided for FY 2013, 2014 \& 2015 as follows:

Table 15: Details of Facility Fee [API and FDF]

\begin{tabular}{|c|c|c|c|c|}
\hline Fiscal Year & \multicolumn{2}{|c|}{ FDF Facility Fee (USD) } & \multicolumn{2}{c|}{ API Facility Fee (USD) } \\
\hline & Domestic (in USA) & Foreign & Domestic (in USA) & Foreign \\
\hline 2013 & 26,458 & 41,458 & 175,389 & 190,389 \\
\hline 2014 & 34,515 & 49,515 & 220,152 & 235,152 \\
\hline 2015 & 41,926 & 56,926 & 247,717 & 262,717 \\
\hline
\end{tabular}

Table 16: Human Generic Application that require Form FDA 3794

\begin{tabular}{|c|l|}
\hline (a) & Abbreviated new drug application (ANDA) or applicable amendment \\
\hline (b) & Prior approval supplement (PAS) or applicable amendment \\
\hline (c) & $\begin{array}{l}\text { Type II active pharmaceutical ingredient (API) drug master file (DMF) that is referenced on } \\
\text { or after October 1, 2012, in a generic drug submission to the FDA and for which the DMF } \\
\text { fee has not already been paid }\end{array}$ \\
\hline (d) & $\begin{array}{l}\text { Generic drug facility which is identified or intended to be identified in at least one generic } \\
\text { drug submission that is pending or approved to produce a finished dosage form (FDF) of a } \\
\text { human generic drug or an API contained in a human generic drug }\end{array}$ \\
\hline (e) & $\begin{array}{l}\text { Backlog ANDA which is pending on October 1, 2012 (applicable only for financial year } \\
\text { (FY) 2013), and that has not received a tentative approval prior to that date }\end{array}$ \\
\hline
\end{tabular}

For fiscal year 2013, the due date for payment of facility was within 45 days after the publication of the Federal Register notice dated January 17, 2013. For each of subsequent fiscal year i.e., 2014 through 2017, the fee will be due on the first business day on or after October 1 of each fiscal year (for all identified facilities).

The established Fee for financial year (FY) 2015 will remain effect through September 30, 2015. Fees for financial years (FYs) 2015-2017 will be adjusted for inflation and other factors, including the number of facilities that have selfidentified each year. The fees will be published in the Federal Register approximately 60 days before the start of each fiscal year.

If a facility manufactures both generic FDFs and APIs, then under GDUFA, such a facility will incur both annual FDF and annual API facility fees.

If any personnel failed to pay the facility fee then there would be several consequences for failure to pay a facility fee. The facility will be placed on a publicly available arrears list if the fee is not fully paid within 20 days of the due date. No new generic drug submission referencing the facility will be received until the fee is paid. Furthermore, all FDFs or APIs manufactured in the non-paying facility and all FDFs containing APIs manufactured in such a facility will be deemed misbranded. This means that it will be a violation of federal law to ship these products in interstate commerce or to import them into the United States. Such violations can result in prosecution of those responsible, injunctions, or seizures of misbranded products. Products misbranded because of failure to pay facility fees are subject to being denied entry into the United States.

\section{Generic Drug User Fee Cover Sheet - Form FDA 3794 (19)}

Per the Generic Drug User Fee Amendments of 2012 (GDUFA), Form FDA 3794 is required to be completed for each of the following human generic drug user fees:

FDA's review of a generic drug submission cannot begin until all applicable user fee obligations have been satisfied. A completed GDUFA Cover Sheet (Form FDA 3794) 
provides the necessary information to determine the total user fee amount required and to help the agency track payments.

\section{User Fee Payment Options and Procedures $(19,20)$}

To make a payment of the fee for DMF or ANDA or PAS or Facility, one must complete a Generic Drug User Fee Cover Sheet (form FDA 3794), available on the FDA Web site (http://www.fda.gov/gdufa) and generate a user fee payment identification (ID) number. Payment must be made in U.S. currency drawn on a U.S. bank by electronic check, check, bank draft, U.S. postal money order, or wire transfer.

The Office of Financial Management (OFM) is responsible for the financial management of the user fee programs. OFM maintains an account receivable system used for user fee invoicing, collections, reporting, and data maintenance.

\section{Exemptions from GDUFA (21)}

Positron Emission Tomography (PET) drug manufacturers are the only human generic drug manufacturers excluded from payment of GDUFA fees. They are, however, required to self-identify. FDA also requests that all drug manufacturers, including generic PET manufacturers, submit a user fee cover sheet with any new FDA submissions. PET manufacturers should complete a generic drug user fee cover sheet for $\$ 0$.

\section{Efforts from FDA to realize the GDUFA effective implementation}

FDA has conducted several public meetings to collect the feedback and released several guidance documents with the agency's expectations as reference documents to generic drug industries. The summary of efforts and documents released/published by FDA since 2010 to till date in order to bring the GDUFA program in reality and to improve the existing review process of generic drug submission have been tabulated below (22):

Table 17: List of Documents/Guidance's/Notices/Rules released by FDA till February 2015

\begin{tabular}{|l|l|l|l|}
\hline \multicolumn{1}{|c|}{ Title of Document } & \multicolumn{1}{|c|}{ Action } & \multicolumn{1}{|c|}{$\begin{array}{c}\text { Docket/ } \\
\text { Document } \\
\text { Number }\end{array}$} & \multicolumn{1}{|c|}{$\begin{array}{c}\text { Published } \\
\text { Date }\end{array}$} \\
\hline $\begin{array}{l}\text { Generic Drug User Fee; Public Meeting; Request for } \\
\text { Comments }\end{array}$ & Notice & $\begin{array}{l}\text { FDA-2010-N- } \\
0381\end{array}$ & $\begin{array}{l}\text { August } \\
2010\end{array}$ \\
\hline $\begin{array}{l}\text { Generic Drug User Fee; Public Meeting; Request for } \\
\text { Comments }\end{array}$ & Notice & $\begin{array}{l}\text { FDA-2010-N- } \\
0381\end{array}$ & $\begin{array}{l}\text { April } \\
2011\end{array}$ \\
\hline $\begin{array}{l}\text { Generic Drug User Fee; Public Meeting; Request for } \\
\text { Comments }\end{array}$ & Notice & $\begin{array}{l}\text { FDA-2010-N- } \\
0381\end{array}$ & July 22, 2011 \\
\hline $\begin{array}{l}\text { Generic Drug User Fee; Public Meeting } \\
\text { Food Dafety and } \\
\text { Innovation Act (FDASIA) }\end{array}$ & An Act & $\begin{array}{l}\text { S. 3187 (Public } \\
\text { Law 112-144) }\end{array}$ & July 09, 2012 \\
\hline $\begin{array}{l}\text { Agency Information Collection Activities; Proposed } \\
\text { Collection; Comment Request; Generic Drug User } \\
\text { Fee Cover Sheet; Form FDA 3794 }\end{array}$ & Notice & $\begin{array}{l}\text { FDA-2012-N- } \\
0748\end{array}$ & July 26, 2012 \\
\hline $\begin{array}{l}\text { Draft Guidance for Industry on Generic Drug User } \\
\text { Fee Amendments of 2012: Questions and Answers; } \\
\text { Availability }\end{array}$ & Notice & $\begin{array}{l}\text { FDA-2012-D- } \\
0880\end{array}$ & $\begin{array}{l}\text { August } \\
2012\end{array}$ \\
\hline $\begin{array}{l}\text { Draft Guidance for Industry on Self-Identification of } \\
\text { Generic Drug Facilities, Sites, and Organizations; } \\
\text { Availability }\end{array}$ & Notice \\
\hline $\begin{array}{l}\text { Generic Drug User Fee Amendments of 2012; } \\
\text { Public Meeting; Request for Comments }\end{array}$ & Notice & $\begin{array}{l}\text { FDA-2012-N- } \\
0882\end{array}$ & $\begin{array}{l}\text { August } \\
2012\end{array}$ \\
\hline
\end{tabular}




\begin{tabular}{|c|c|c|c|}
\hline $\begin{array}{l}\text { Notice of Opportunity To Withdraw Abbreviated } \\
\text { New Drug Applications To Avoid Backlog Fee } \\
\text { Obligations }\end{array}$ & Notice & $\begin{array}{l}\text { FDA-2012-N- } \\
0879\end{array}$ & $\begin{array}{l}\text { August } \\
2012\end{array}$ \\
\hline $\begin{array}{l}\text { Draft Guidance for Industry on Initial } \\
\text { Completeness Assessments for Type II Active } \\
\text { Pharmaceutical Ingredient Drug Master Files Under } \\
\text { the Generic Drug User Fee Amendments of } 2012\end{array}$ & Notice & $\begin{array}{l}\text { FDA-2012-D- } \\
1010\end{array}$ & $\begin{array}{l}\text { October } 02 \\
2012\end{array}$ \\
\hline $\begin{array}{l}\text { Generic Drug Facilities, Sites and } \\
\text { Organizations - Self Identification Process }\end{array}$ & $\begin{array}{l}\text { Notice of } \\
\text { Requirem } \\
\text { ent }\end{array}$ & $\begin{array}{l}\text { FDA-2012-N- } \\
1006\end{array}$ & $\begin{array}{l}\text { October } 02 \\
2012\end{array}$ \\
\hline FDA User Fee Correction Act of 2012 & An Act & \begin{tabular}{ll|} 
H.R.6433 & \\
(Public & Law \\
$112-193)$ & \\
\end{tabular} & $\begin{array}{l}\text { October } 05 \\
2012\end{array}$ \\
\hline $\begin{array}{l}\text { Generic Drug User Fee-Abbreviated New Drug } \\
\text { Application, Prior Approval Supplement, and Drug } \\
\text { Master File Fee Rates for Fiscal Year } 2013\end{array}$ & Notice & $\begin{array}{l}\text { FDA-2012-N- } \\
0007\end{array}$ & $\begin{array}{l}\text { October } 25 \\
2012\end{array}$ \\
\hline $\begin{array}{l}\text { Generic Drug User Fee-Backlog Fee Rate for } \\
\text { Fiscal Year } 2013\end{array}$ & Notice & $\begin{array}{l}\text { FDA-2012-N- } \\
0007\end{array}$ & $\begin{array}{l}\text { October } 25 \\
2012\end{array}$ \\
\hline $\begin{array}{l}\text { Generic Drug User Fee-Active Pharmaceutical } \\
\text { Ingredient and Finished Dosage Form Facility Fee } \\
\text { Rates for Fiscal Year } 2013\end{array}$ & Notice & $\begin{array}{l}\text { FDA-2013-N- } \\
0007\end{array}$ & $\begin{array}{l}\text { January } \\
2013\end{array}$ \\
\hline $\begin{array}{l}\text { Generic Drug Facilities, Sites, and Organizations - } \\
\text { Self Identification Process }\end{array}$ & Notice & $\begin{array}{l}\text { FDA-2013-N- } \\
0391 \\
\end{array}$ & $\begin{array}{l}\text { April } \\
2013 \\
\end{array}$ \\
\hline $\begin{array}{l}\text { Generic Drug User Fee Amendments of 2012; } \\
\text { Regulatory Science Initiatives Public Hearing; } \\
\text { Request for Comments }\end{array}$ & $\begin{array}{l}\text { Notificatio } \\
\mathrm{n} \text { of public } \\
\text { hearing }\end{array}$ & $\begin{array}{l}\text { FDA-2013-N- } \\
0402\end{array}$ & $\begin{array}{l}\text { May } \\
2013\end{array}$ \\
\hline $\begin{array}{l}\text { Generic Drug User Fee-Abbreviated New Drug } \\
\text { Application, Prior Approval Supplement, Drug } \\
\text { Master File, Final dosage Form Facility, and Active } \\
\text { Pharmaceutical Ingredient Facility Fee Rates for } \\
\text { Fiscal Year } 2014\end{array}$ & Notice & $\begin{array}{l}\text { FDA-2013-N- } \\
0007\end{array}$ & $\begin{array}{l}\text { August } \\
2013\end{array}$ \\
\hline $\begin{array}{l}\text { Draft Guidance for Industry on Generic Drug User } \\
\text { Fee Amendments of 2012: Questions and Answers } \\
\text { (Revision 1); Availability }\end{array}$ & Notice & $\begin{array}{l}\text { FDA-2012-D- } \\
0880\end{array}$ & $\begin{array}{l}\text { September } \\
10,2013\end{array}$ \\
\hline $\begin{array}{l}\text { Draft Guidance for Industry on Abbreviated New } \\
\text { Drug Application Submissions-Refuse-to-Receive } \\
\text { Standards; Availability }\end{array}$ & Notice & $\begin{array}{l}\text { FDA-2013-D- } \\
1120\end{array}$ & $\begin{array}{l}\text { October } \\
2013\end{array}$ \\
\hline $\begin{array}{l}\text { Draft Guidance for Industry on Generic Drug User } \\
\text { Fee Amendments of 2012: Questions and Answers } \\
\text { (Revision 1); }\end{array}$ & $\begin{array}{l}\text { Notice; } \\
\text { reopening } \\
\text { of the } \\
\text { comment } \\
\text { period. }\end{array}$ & $\begin{array}{l}\text { FDA-2012-D- } \\
0880\end{array}$ & $\begin{array}{l}\text { November } \\
27,2013\end{array}$ \\
\hline $\begin{array}{l}\text { Draft Generic Drug User Fee Act Information } \\
\text { Technology Plan; Availability for Comment }\end{array}$ & Notice & $\begin{array}{l}\text { FDA-2013-N- } \\
1615\end{array}$ & $\begin{array}{l}\text { December } \\
26,2013\end{array}$ \\
\hline $\begin{array}{l}\text { Improving the Quality of Abbreviated New Drug } \\
\text { Application Submissions to the Food and Drug } \\
\text { Administration; Establishment of a Public Docket }\end{array}$ & Notice & $\begin{array}{l}\text { FDA-2014-N- } \\
0032\end{array}$ & $\begin{array}{l}\text { January } \\
2014\end{array}$ \\
\hline
\end{tabular}




\begin{tabular}{|c|c|c|c|}
\hline $\begin{array}{l}\text { Guidance for Industry; Providing Regulatory } \\
\text { Submissions in Electronic Format-Receipt Date; } \\
\text { Availability }\end{array}$ & Notice & $\begin{array}{l}\text { FDA-2007-D- } \\
0077\end{array}$ & $\begin{array}{l}\text { February } \\
2014\end{array}$ \\
\hline $\begin{array}{l}\text { Draft Guidance for Industry on Abbreviated New } \\
\text { Drug Application Submissions; Content and Format } \\
\text { of Abbreviated New Drug Applications; Availability }\end{array}$ & Notice & $\begin{array}{l}\text { FDA-2014-D- } \\
0725\end{array}$ & $\begin{array}{l}\text { June } \\
2014\end{array}$ \\
\hline $\begin{array}{l}\text { Draft Guidance for Industry on Abbreviated New } \\
\text { Drug Application Submissions; Amendments and } \\
\text { Easily Correctable Deficiencies Under the Generic } \\
\text { Drug User Fee Amendments; Availability }\end{array}$ & Notice & $\begin{array}{l}\text { FDA-2014-D- } \\
0902\end{array}$ & July 11,2014 \\
\hline $\begin{array}{l}\text { Draft Guidance for Industry on Abbreviated New } \\
\text { Drug Application Submissions-Prior Approval } \\
\text { Supplements Under the Generic Drug } \\
\text { User Fee Amendments of } 2012 \text {; Availability }\end{array}$ & Notice & $\begin{array}{l}\text { FDA-201 } \\
0901\end{array}$ & July 11,2014 \\
\hline $\begin{array}{l}\text { Generic Drug User Fee - Abbreviated } \\
\text { New Drug Application, Prior Approval Supplement, } \\
\text { Drug Master File, Final Dosage Form Facility, and } \\
\text { Active Pharmaceutical Ingredient Facility Fee Rates } \\
\text { for Fiscal Year } 2015\end{array}$ & Notice & $\begin{array}{l}\text { FDA-2014-N- } \\
0007\end{array}$ & $\begin{array}{l}\text { August } \\
2014\end{array}$ \\
\hline $\begin{array}{l}\text { Generic Drug User Fee Amendments of 2012; } \\
\text { Public Hearing on Policy Development; Request for } \\
\text { comments }\end{array}$ & $\begin{array}{l}\text { Proposed } \\
\text { Rules }\end{array}$ & $\begin{array}{l}\text { FDA-2014-N- } \\
1168\end{array}$ & $\begin{array}{l}\text { August } \\
2014\end{array}$ \\
\hline $\begin{array}{lllr}\text { Draft Guidance for Industry } & \text { on Controlled } \\
\text { Correspondence } & \text { Related to Generic Drug } \\
\text { Development; Availability } & & & \\
\end{array}$ & Notice & $\begin{array}{l}\text { FDA-2014-D- } \\
1167\end{array}$ & $\begin{array}{l}\text { August } \\
2014\end{array}$ \\
\hline $\begin{array}{l}\text { Guidance for Industry on Abbreviated New Drug } \\
\text { Application } \quad \text { Submissions- } \quad \text { Refuse-to-Receive } \\
\text { Standards; Availability }\end{array}$ & Notice & $\begin{array}{l}\text { FDA-2013-D- } \\
1120\end{array}$ & $\begin{array}{l}\text { September } \\
17,2014\end{array}$ \\
\hline $\begin{array}{l}\text { Draft Guidance for Industry on Abbreviated New } \\
\text { Drug Application Submissions - Refuse To Receive } \\
\text { for Lack of Proper Justification of Impurity Limits; } \\
\text { Availability }\end{array}$ & Notice & $\begin{array}{l}\text { FDA-2014-D- } \\
1292\end{array}$ & $\begin{array}{l}\text { September } \\
17,2014\end{array}$ \\
\hline $\begin{array}{l}\text { Proposed Criteria for "First Generic" Submissions } \\
\text { for Purposes of Abbreviated New Drug Application } \\
\text { Review Prioritization Under the Generic Drug User } \\
\text { Fee Amendments; }\end{array}$ & $\begin{array}{l}\text { Notice; } \\
\text { establishm } \\
\text { ent of } \\
\text { public } \\
\text { docket; } \\
\text { request for } \\
\text { comments }\end{array}$ & $\begin{array}{l}\text { FDA-2014-N- } \\
1741\end{array}$ & $\begin{array}{l}\text { November } \\
19,2014\end{array}$ \\
\hline $\begin{array}{l}\text { Abbreviated New Drug Applications and 505(b)(2) } \\
\text { Applications; }\end{array}$ & $\begin{array}{l}\text { Proposed } \\
\text { Rule }\end{array}$ & $\begin{array}{l}\text { FDA-2011-N- } \\
0830\end{array}$ & $\begin{array}{l}\text { February } 6 \text {, } \\
2015\end{array}$ \\
\hline $\begin{array}{l}\text { Generic Drug User Fee Amendments of 2012; } \\
\text { September } 2014 \text { Public Hearing on Policy } \\
\text { Development; Reopening of Docket; Request for } \\
\text { Comments }\end{array}$ & $\begin{array}{l}\text { Notice; } \\
\text { reopening } \\
\text { of docket; } \\
\text { request for } \\
\text { comments }\end{array}$ & $\begin{array}{l}\text { FDA-2014-N- } \\
1168\end{array}$ & $\begin{array}{l}\text { February } \\
2015\end{array}$ \\
\hline
\end{tabular}

After GDUFA implementation, a generic applicant has to comply with all requirements of GDUFA apart from the general requirements to prepare an Abbreviated New Drug Application i.e., getting drug substances from approved vendors, finished product development, clinical studies, plant inspection, dossier writing and finally submission to authorities. The diagram 
(Figure 2) illustrates the various elements product post GDUFA. involved in obtaining approval for a generic

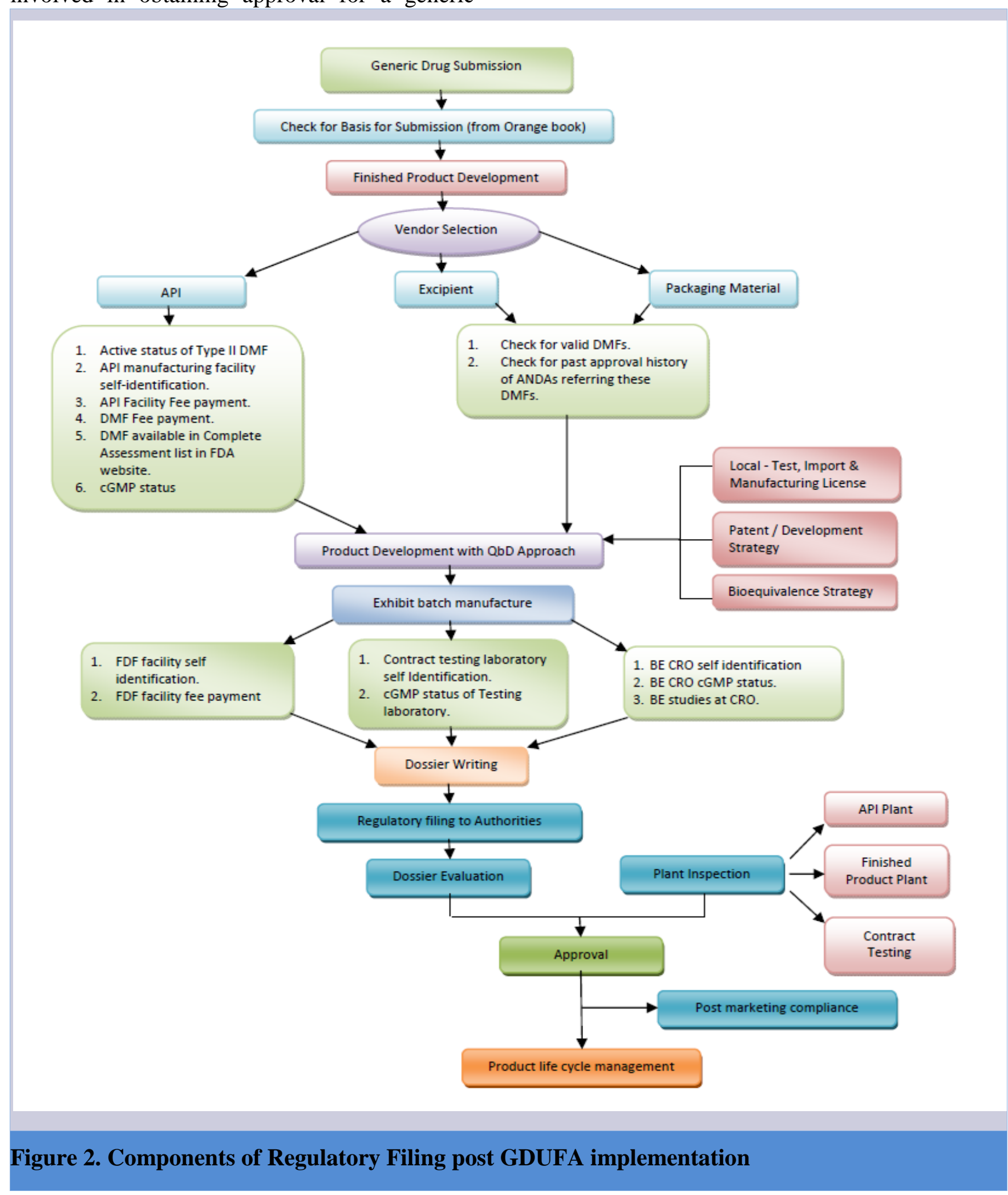

Comparison of few elements in the requirements and review process of Generic drug Application pre and post GDUFA implementation are tabulated below:

Table 18: Comparison of elements of ANDA review Pre and Post GDUFA implementation 


\begin{tabular}{|c|c|c|}
\hline Element & Pre GDUFA & Post GDUFA \\
\hline $\begin{array}{l}\text { Self Identification of } \\
\text { facilities and Laboratories }\end{array}$ & Not in place. & $\begin{array}{l}\text { Required to identify all the facilities } \\
\text { annually. }\end{array}$ \\
\hline $\begin{array}{l}\text { Facility Fee (API and } \\
\text { FDF) }\end{array}$ & Not in place. & Required to pay the fee annually. \\
\hline $\begin{array}{l}\text { DMF Fee (for Active } \\
\text { pharmaceutical } \\
\text { ingredient) }\end{array}$ & Not in place. & Required to pay at once. \\
\hline $\begin{array}{l}\text { DMF } \\
\text { Assessment }\end{array}$ & Not in place. & $\begin{array}{l}\text { Completeness Assessment of Type II } \\
\text { DMF is mandatory in order to take up } \\
\text { the ANDA for review (CA must be } \\
\text { completed before ANDA submission } \\
\text { date) }\end{array}$ \\
\hline Deficiency letter & $\begin{array}{l}\text { Issuing of Deficiency letters } \\
\text { division wise i.e., CMC, } \\
\text { DBE, Microbiology and } \\
\text { Labeling. }\end{array}$ & $\begin{array}{l}\text { Complete } \\
\text { collecting deficiencies from all } \\
\text { divisions i.e., CMC, DBE, } \\
\text { Microbiology, Labeling and } \\
\text { Inspections and other miscellaneous. }\end{array}$ \\
\hline & Major, Minor Amendment & $\begin{array}{llr}\text { Tier system introduced } & \text { with } \\
\text { terminology of Solicited } & \text { and } \\
\text { Unsolicited Amendments } & \text { with } \\
\text { defined review goals } & \\
\end{array}$ \\
\hline Amendment categories & Telephone Amendment & $\begin{array}{l}\text { Information Request and Easily } \\
\text { correctable deficiencies and in future } \\
\text { FDA is planning to introduce Real } \\
\text { time communication for resolving the } \\
\text { minor deficiencies in minimum time } \\
\text { to meet review goal }\end{array}$ \\
\hline Goal Date for Approval & Not specified. & $\begin{array}{l}\text { Goal date will be specified in the } \\
\text { acceptance letter by OGD. }\end{array}$ \\
\hline $\begin{array}{l}\text { Typical review time for } \\
\text { Generic Drug Application } \\
\text { approval }\end{array}$ & $\begin{array}{l}\text { The current median time for } \\
\text { review of a new generic drug } \\
\text { application is } 31 \text { months } \\
\text { depending on the application } \\
\text { quality and patent strategy. }\end{array}$ & $\begin{array}{l}\text { FDA aspires to reduce the review time } \\
\text { substantially; tentatively minimum } 10 \\
\text { months and maximum may be } 33 \\
\text { months depending on the application } \\
\text { quality and patent strategy, litigation } \\
\text { etc. }\end{array}$ \\
\hline $\begin{array}{l}\text { Limitation of number of } \\
\text { Amendments during under } \\
\text { review of ANDA (CMC } \\
\text { Changes) }\end{array}$ & $\begin{array}{l}\text { No limitation } r \text { for } \\
\text { Amendments, can propose } \\
\text { changes during } \\
\text { filing. }\end{array}$ & $\begin{array}{l}\text { As number of Amendments increases, } \\
\text { review time for application will be } \\
\text { extended and may not be approved as } \\
\text { per the given Goal date. So, good } \\
\text { quality of Application will be } \\
\text { approved early as per goal date. }\end{array}$ \\
\hline PAS Submission & $\begin{array}{l}\text { No Fee is incurred, and the } \\
\text { review time of the application } \\
\text { is not defined and the } \\
\text { approval time ranges from } 12 \\
\text { month to } 24 \text { months. }\end{array}$ & $\begin{array}{l}\text { PAS Fee will be incurred. However, } \\
\text { clear goal date for approval of the } \\
\text { application will be defined ( } 6 \text { month } \\
\text { or } 10 \text { months depending necessity of } \\
\text { facility inspection). }\end{array}$ \\
\hline
\end{tabular}




\begin{tabular}{|l|l|l|}
\hline Control Correspondence & $\begin{array}{l}\text { Response for control } \\
\text { correspondence has no time } \\
\text { limitation. }\end{array}$ & $\begin{array}{l}\text { Targeted to respond minimum 2 } \\
\text { months and maximum } 4 \text { months (if } \\
\text { inputs required from Clinical } \\
\text { division). }\end{array}$ \\
\hline cGMP Inspections & $\begin{array}{l}\text { Frequency of Inspection has } \\
\text { not been defined. }\end{array}$ & $\begin{array}{l}\text { FDA will conduct risk-adjusted } \\
\text { biennial cGMP surveillance } \\
\text { inspections of generic API and generic } \\
\text { finished dosage form (FDF) } \\
\text { manufacturers. }\end{array}$ \\
\hline $\begin{array}{l}\text { Refuse to Receive } \\
\text { standards (23) }\end{array}$ & $\begin{array}{l}\text { A guidance document has been } \\
\text { released by FDA recommending to } \\
\text { follow for the preparation of good } \\
\text { quality application in order to get the } \\
\text { approval early i.e., goal date given by } \\
\text { FDA. }\end{array}$ \\
\hline $\begin{array}{l}\text { Nenalty to Refuse to } \\
\text { Receive }\end{array}$ & No specific penalty defined. & $\begin{array}{l}\text { Penalty would be in terms of Fee i.e., } \\
\text { If FDA refuse to receive the } \\
\text { application other than the reason of } \\
\text { fee payment, then only 75\% of the } \\
\text { paid fee be refunded to the applicant. }\end{array}$ \\
\hline
\end{tabular}

\section{CONCLUSION}

The implementation of GDUFA program is yielding good improvements in FDA's division of Office of Generic Drugs (OGD) i.e., advancing/improving the review pattern of a generic application without compromising quality and efficacy for intended use of generic product. Further, FDA is planning to increase the staff to assess the Risk based quality approach and making every effort to allow the generic drugs in to the market for availability of patients/customers. Thus, the implementation of Generic Drug User Fee program benefits customers economically and benefits generic industries in facilitating early launch of generic products into the market.

\section{Benefits to the consumers:}

(a) Access - GDUFA will expedite the availability of low-cost, high-quality generic drugs by bringing greater predictability and timeliness to the FDA review process.

(b) Quality - GDUFA will help in increasing the safety and quality of the drugs required by the customers. Further, it helps in establishing a system to assure the high quality standards of generic drug manufacturing facilities (both foreign and domestic) at the same consistent level with very frequent inspections i.e., once every two years using a risk-based approach.

(c) Transparency - Under GDUFA, all facilities involved in the manufacture of generic drugs and their ingredients, both domestic and foreign, must be identified. This mandated identification system enhances the transparency in knowing the number of facilities involved in the manufacture of Generic Drugs and help FDA to protect customers in today's complex global supply environment.

\section{Benefits to Industry}

(a) GDUFA will deliver greater predictability and timeliness to the review of generic drug applications, slashing review times and saving industry time and money.

(b) Under GDUFA, based on an agreement negotiated by FDA and representatives of the generic drug industry, FDA will further modernizes the generic drug approval program time to time and sets new performance goals for initiatives to encourage the sooner availability of generics in the market.

(c) The annual fee total for GDUFA represents only about one half of 1 percent of generic drug sales. This relatively small cost to the 
industry could be offset by faster review times that bring products to market sooner.

\section{ACKNOWLEDGEMENTS}

I express my gratitude to my family members and Management of Daewoong Pharmaceutical Co. Ltd., India for supporting me in writing this article. The contents of this article are the sole responsibility of the authors and do not necessarily reflect the views of Daewoong Pharmaceutical Co. Ltd, India.

\section{CONFLICT OF INTEREST}

Author declares that there are no conflicts of interest.

\section{REFERENCES}

1. What are Generic Drugs - Office of Generic Drugs [Internet]. U.S. Food and Drug Administration, Silver Spring, USA [date unknown] [cited 2009 May 12]. Available from:

http://www.fda.gov/Drugs/ResourcesForYou/Consu mers/BuyingUsingMedicineSafely/UnderstandingGe nericDrugs/ucm144456.htm

2. Understanding Generic Drugs - Office of Generic Drugs [Internet]. U.S. Food and Drug Administration, Silver Spring, USA [date unknown] [cited 2014 Oct 23]. Available from: http://www.fda.gov/drugs/resourcesforyou/consumers /buyingusingmedicinesafely/understandinggenericdru gs/default.htm

3. Human Generic Drug Performance Goals and Procedures Fiscal Years 2013 through 2017 - U.S. Food and Drug Administration [Internet]. U.S. Food and Drug Administration, Silver Spring, USA [2012 July 17] [cited 2012 Sept 09]. Available from: http://www.fda.gov/ForIndustry/UserFees/GenericDr ugUserFees/ucm282513.htm

4. Ramesh T, Saravanan D, and Khullar P. Regulatory Perspective for Entering Global Pharma Markets. Pharma Times. Volume 43. No. 09; 2011 Sept.

5. Federal Food, Drug, and Cosmetic Act revised - U.S. Food and Drug Administration [Internet]. U.S. Food and Drug Administration, Silver Spring, USA [2012 July 09] [cited 2014 Feb 26]. Available from: http://www.gpo.gov/fdsys/pkg/BILLS-

112s3187enr/pdf/BILLS-112s3187enr.pdf

6. Generic Drug User Fee Amendments of 2012 Guidance document [Internet]. U.S. Food and Drug Administration, Silver Spring, USA [2013 Sept 10] [cited 2014 Aug 22]. Available from: http://www.fda.gov/downloads/Drugs/GuidanceCom plianceRegulatoryInformation/Guidances/UCM3166 71.pdf

7. Generic Drug User Fee-Backlog Fee Rate for Financial Year 2013 - Federal Register [Internet]. U.S. Food and Drug Administration, Silver Spring,
USA [2012 Oct 25] [cited 2012 Oct 25]. Available from:

http://www.gpo.gov/fdsys/pkg/FR-2012-10-25/pdf/ 2012-26257.pdf

8. Notice of Opportunity To Withdraw Abbreviated New Drug Applications To Avoid Backlog Fee Obligations - Federal Register [Internet]. U.S. Food and Drug Administration, Silver Spring, USA [2012 Aug 27] [cited 2012 Aug 27]. Available from: http://www.gpo.gov/fdsys/pkg/FR-2012-0827/html/2012-20947.htm

9. Generic Drug User Fee Amendments of 2012 - U.S. Food and Drug Administration [Internet]. U.S. Food and Drug Administration, Silver Spring, USA [date unknown] [cited $2015 \mathrm{Feb} 12$ ]. Available from: http://www.fda.gov/forindustry/userfees/genericdrug userfees/default.htm

10. Generic Drug User Fee-Abbreviated New Drug Application, Prior Approval Supplement, and Drug Master File Fee Rates for Fiscal Year 2013 - Federal Register [Internet]. U.S. Food and Drug Administration, Silver Spring, USA [2012 Oct 25] [cited 2012 Oct 25]. Available from: http://www.gpo.gov/fdsys/pkg/FR-2012-1025/pdf/2012-26256.pdf

11. Generic Drug User Fee-Abbreviated New Drug Application, Prior Approval Supplement, Drug Master File, Final Dosage Form Facility, and Active Pharmaceutical Ingredient Facility Fee Rates for Fiscal Year 2014 - Federal Register [Internet]. U.S. Food and Drug Administration, Silver Spring, USA [2013 Aug 2] [cited 2013 Aug 2]. Available from: http://www.gpo.gov/fdsys/pkg/FR-2013-0802/pdf/2013-18625.pdf

12. Generic Drug User Fee - Abbreviated New Drug Application, Prior Approval Supplement, Drug Master File, Final Dosage Form Facility, and Active Pharmaceutical Ingredient Facility Fee Rates for Fiscal Year 2015 - Federal Register [Internet]. U.S. Food and Drug Administration, Silver Spring, USA [2014 Aug 1] [cited 2014 Aug 1]. Available from: http://www.gpo.gov/fdsys/pkg/FR-2014-0801/pdf/2014-18108.pdf

13. Initial Completeness Assessment for Type II API DMFs Under GDUFA - Guidance Document [Internet]. U.S. Food and Drug Administration, Silver Spring, USA [2012 Oct 02] [cited 2014 Aug 22]. Available from:

http://www.fda.gov/downloads/Drugs/GuidanceCom plianceRegulatoryInformation/Guidances/UCM3218 84.pdf

14. Abbreviated New Drug Application (ANDA) and Prior Approval Supplement (PAS) Fees - Question and Answers [Internet]. U.S. Food and Drug Administration, Silver Spring, USA [date unknown] [cited 2014 July 31]. Available from: http://www.fda.gov/ForIndustry/UserFees/GenericDr ugUserFees/ucm319568.htm

15. Generic Drug Facilities, Sites and Organizations self Identification - Federal Register [Internet]. U.S. Food and Drug Administration, Silver Spring, USA [2012 Oct 2] [cited 2012 Oct 2]. Available from: 
http://www.gpo.gov/fdsys/pkg/FR-2012-10-

02/pdf/2012-24326.pdf

16. Generic Drug Facilities, Sites and Organizations self Identification - Federal Register [Internet]. U.S. Food and Drug Administration, Silver Spring, USA [2013 April 16] [cited 2013 April 16]. Available from: http://www.gpo.gov/fdsys/pkg/FR-2013-0416/pdf/2013-08806.pdf

17. Generic Drug User Fee-Active Pharmaceutical Ingredient and Finished Dosage Form Facility Fee Rates for Fiscal Year 2013 - Federal Register [Internet]. U.S. Food and Drug Administration, Silver Spring, USA [2013 Jan 17] [cited 2013 Jan 17]. Available from: http://www.gpo.gov/fdsys/pkg/FR-2013-0117/pdf/2013-00851.pdf

18. Facility Fee - Question and Answers [Internet]. U.S. Food and Drug Administration, Silver Spring, USA [date unknown] [cited 2014 July 31]. Available from: http://www.fda.gov/ForIndustry/UserFees/GenericDr ugUserFees/ucm319566.htm

19. User Fee Cover Sheets - U.S. Food and Drug Administration [Internet]. U.S. Food and Drug Administration, Silver Spring, USA [date unknown] [cited 2014 Oct 24]. Available from: http://www.fda.gov/ForIndustry/UserFees/default.ht $\mathrm{m}$

20. Generic Drug User Fee Cover Sheet and Payment Information - U.S. Food and Drug Administration [Internet]. U.S. Food and Drug Administration, Silver Spring, USA [date unknown] [cited 2014 Aug 08]. Available from: http://www.fda.gov/ForIndustry/UserFees/GenericDr ugUserFees/ucm322629.htm

21. Other Fee Related Questions - Question and Answers [Internet]. U.S. Food and Drug Administration, Silver Spring, USA [date unknown] [cited 2013 Jun 21]. Available from:

http://www.fda.gov/ForIndustry/UserFees/GenericDr ugUserFees/ucm319572.htm

22. FDSYS - Federal Digital System [Internet]. U.S. Government of Publishing Office, Washington, DC, USA [date unknown] [cited date unknown]. Available from: http://www.gpo.gov/fdsys/search/home.action

23. CDER Small Business Webinar on Guidance for Industry: ANDA Submission - Refuse-to-receive Standards - U.S. Food and Drug Administration [Internet]. U.S. Food and Drug Administration, Silver Spring, USA [2013 Nov 18] [cited 2013 Nov 11]. Available from: http://www.fda.gov/Drugs/DevelopmentApprovalPro cess/SmallBusinessAssistance/ucm374375.htm 